Once the volunteers resumed ordinary life, their physiology quickly returned to normal, so that, according to Kakurin "space flight is not limited to six months. The human organism has genuinely unlimited possibilities".

On board experiments, however, are the only sure way of determining the effects of weightlessness. The biological programme of Salyut- 6 includes both human and non-human tests. Certain of the latter seem somewhat esotericas, for example the result that tadpoles hatched in space swim in spirals, while earth-hatched tadpoles swim in a more "disorderly" manner. Other Salyut-6 experiments, monitoring the total effect of space rather than weightlessness alone, include the Franco-Soviet Cytos experiments on micro-organism cell division, a genetic investigation using Drosophila (banned from Soviet research at the height of Lysenkoism) and the somewhat ominously named "Medusa" experiment which compares the effect of space-flight on biopolymers in and outside the station.

The main source of medical data is, however, the on-board monitoring of cosmonauts. The Salyut-6 tests have included electrocardiograms, encephalograms and rheograph and manometer investigations, used at "rest" and after exercise on the "running track" and "veloenergometer". A special self-contained microanalysis kit was used to enable the cosmonauts to take samples of each other's blood; these were returned to earth by the Soyuz-26 craft.

The possibility of returning specimens in this way has greatly extended the facilities for maintaining the cosmonauts' health and well-being. Similarly the use of unmanned supply rockets will enable any necessary medicines to be taken into orbit. Progress-1 did, in fact, carry a replacement medicine chest-since although the original one had not been broached, it was felt that certain medicaments might have grown stale and lost their efficacy.

The use of replacement crews and supply rockets, however, has far more significance to cosmonaut health than simply that of keeping the life-support systems operative and the supplies recharged. The Salyut-6 planners have laid great emphasis on the physical comfort and psychological well-being of the cosmonauts. Station noise has been reduced by siting the motors "further astern" and installing "quieter switches". A shower has been installed (a triumph of ingenious design) and semi-rigid spacesuits are used for EVA which are said to simulate gravity by directing pressure to the lower parts of the body. The on-board menu includes over 60 named brands of food.

Nevertheless, all is not entirely happy aboard Salyut-6. The TV set ferried up by Progress-1 was said to be urgently needed, to keep the crew in touch with world events. One cosmonaut mentioned that after 45 days in orbit there was a need for "any kind of moral support"; it was a great boost, he said, to know that the completed experiments returned for processing via Salyut-26 had turned out well. Clearly, one of the main problems of small-crew long-term space-stations is likely to be that of psychological isolation-a factor which will undoubtedly increase as such stations become a matter of routine rather than headline news. One can only hope that in the future, relieving or supply crews will be less careless than Dzhanibekov and Makarov, who in the excitement of undocking from the first four-man Salyut-link-up left behind the letters home of Romanenko and Grechko.

Vera Rich

\title{
USSR moves to protect rare animals
}

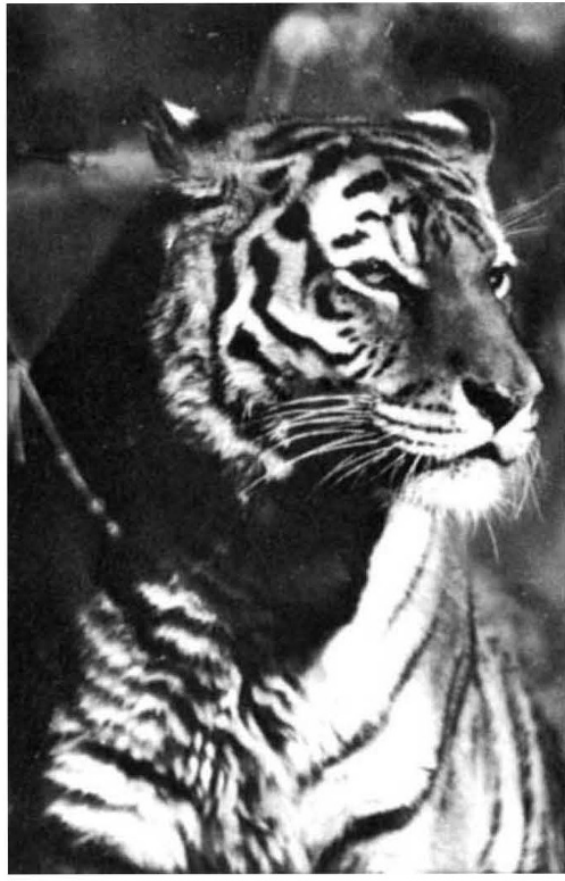

Vanishing species: the Amur tiger . . .

THE Sovict Union is preparing new legislation governing the conservation of rare fauna and restrictions on hunting. The December 1972 Resolution of the Central Committee and Supreme Soviet "on increasing the protection of nature and improving the use of natural resources", placed an emphasis on ecology that had been largely lacking in Soviet official thought, but so far its provisions have proved impossible to implement.

According to N. Eliseev, head of Glavokhota (Principal Hunting Trust) of the Russian Soviet Federative Socialist Republic (RSFSR), the poaching of rare and protected species is still rife. The RSFSR is by far the largest of the Union Republics, comprising Russia proper and the major part of Soviet Asia. Eliseev's department is thus responsible for $80 \%$ of all furbearing animals and $90 \%$ of all birdlife in the Soviet Union, including such rare and vanishing species as the Amur

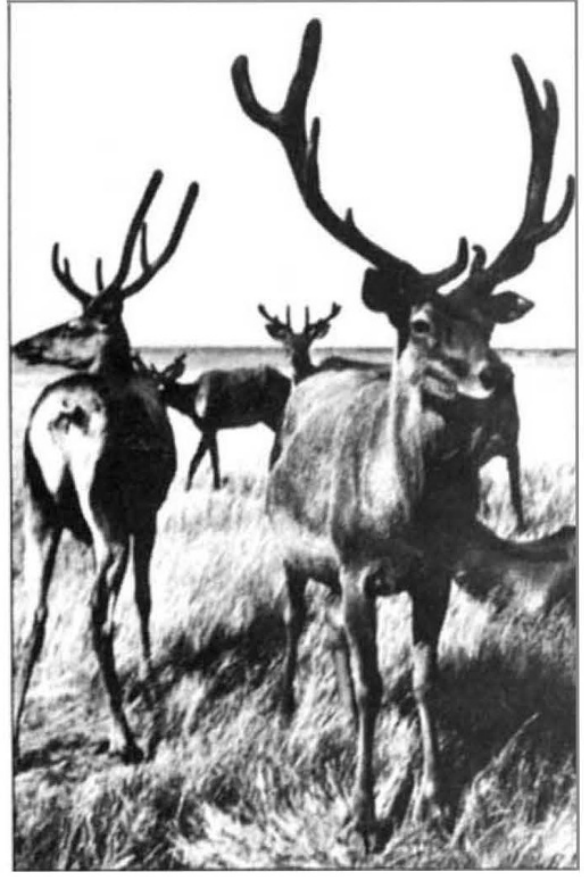

and goral

tiger, the goral and the desman (source of musquash).

Hunting is still an important industry (since in much of the Soviet Union fur is a necessary rather than a luxury article) and it is governed by a somewhat complicated system of inspections and licences. But the poachers often manage to circumvent the various controls by making rapid safaris in fast cars and motor boats. Poaching, or at any rate, breaches of the hunting regulations on the part of licensed hunters, are common.

The new laws, says Fliseev, "will intensify the protection of wild animals, hirds, fish and other fauna". Presumably this means (though he does not say so) severe penalties for poachers and dishonest hunters. F.liseev, however, stresses the positive approach to conservation, demanding a fundamental change in social attitude: "An end must be put to the consumer attitude towards nature". 